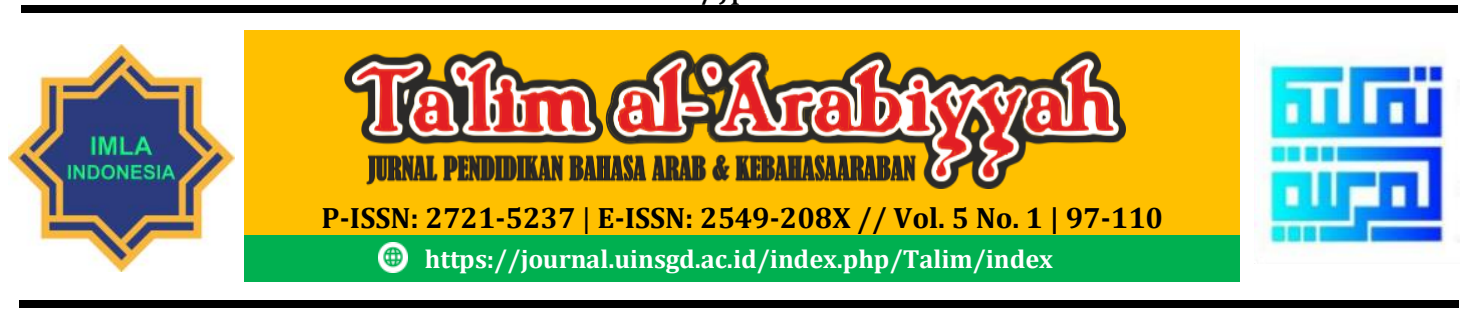

\title{
Recitation: An Alternative Method For Virtual Nahwu Learning
}

\author{
Frida Akmalia ${ }^{1}$, Khoirul Faizin ${ }^{2}$ \\ ${ }^{1}$ Universitas Pendidikan Indonesia Bandung, Indonesia \\ ${ }^{2}$ Universitas Sunan Ampel Surabaya, Indonesia \\ Corresponding E-mail: fridaakmalia26@upi.edu
}

\begin{abstract}
This research is based on the learning state that requires maximum learning even during the pandemic. The researchers assume that the recitation method in virtual nabwu learning can be used to overcome this problem. Then the researchers conducted an initial study, observation, and conducted experiments in a particular class. With observation, the researchers can examine the implementation of virtual nahwu learning. Whereas with experiments, the researchers found that this method is very relevant and could be an option for virtual nabwu learning at STAI Attanwir. It is evidenced by the results of the experimental class's average values before using this method were 67.94 (experimental) and 66.93 (control). After applying the learning method, it was found that the average value was 85.2 for the experimental group and 74.7 for the control group. This result is helpful as an illustration of the virtual Nahwu learning method and a reference for future researchers.
\end{abstract}

Keywords: Nahwu, Recitation Methode, Virtual Arabic Learning.

\section{ABSTRAK}

Penelitian ini berawal dari keadaan pembelajaran yang mengharuskan pembelajaran tetap berjalan maksimal meski di tengah pandemi. Peneliti berasumsi bahwa metode resitasi dalam pembelajaran nahwu virtual bisa dijadikan salah satu solusi untuk mengatasi masalah tersebut. Kemudian peneliti melakukan kajian awal, observasi, serta eksperimen pada kelas khusus. Dengan observasi, peneliti bisa mengkaji implementasi pembelajaran nahwu virtual. Sedangkan dengan eksperimen, peneliti menemukan bahwa metode ini sangat relevan dan bisa menjadi salah satu pilihan untuk digunakan dalam pembelajaran nahwu virtual di STAI Attanwir. Hal tersebut dibuktikan dengan hasil nilai rata-rata kelas eksperimen yang sebelum menggunakan metode ini adalah 67,94 (eksperimen) dan 66,93 (Kontrol). Kemudian setelah diterapkan metode pembelajaran, ditemukan nilai rata-rata menjadi 85,2 untuk kelompok eksperimen dan 74,7 untuk kelompok kontrol. Hasil ini bermanfaat sebagai gambaran tentang metode pembelajaran nahwu secara virtual dan referensi peneliti di masa depan.

Kata Kunci: Nahwu, Metode Resitasi, Pembelajaran Bahasa Arab Virtual. 
Ta'lim al-'Arabiyyah : Jurnal Pendidikan Bahasa Arab dan Kebahasaaraban, 5 (1), 2021

\section{INTRODUCTION}

Arabic language education has become a significant concern in education around the world (Blignault, et al., 2019; El Rahman, 2020; Isani, 2021; Pereira, 2017; Thomure, 2018) during the last five decades, especially during the pandemic (Akmaliyah, et al., 2020; Hilmi, et al., 2020; Ibrahim, 2020; Mabruri, et al., 2021; Wargadinata, et al., 2020). For instance, in Indonesia there were several studies of Arabic language learning during the pandemic; teaching media (Ahmadi \& Ilmiani, 2020; Nurcholis, et al., 2021), cognitive structures (Jazeeh, et al., 2021), learning management (Yahya, 2021), teaching and learning (Moghazy, 2020), website (Jusni \& Ardiansyah, 2020), and learning evaluation (Thohir, et al., 2020). Thus, Arabic language education has become an important study in various aspects.

Language learners (e.g., Arabic) are currently accustomed to incorporating technology into the learning experience and expect opportunities to engage and interact (Kessler, 2018). To interact appropriately, it is necessary to have learning methods that can support lessons during a pandemic. Such as virtual Arabic learning (e.g., nahww using a recitation method. In the learning aspect, the recitation method is often used in various learning fields such as; Islamic religious education (Halik \& Yusfira, 2019; Mariyam, etc., 2018), computer programming (Murniasih \& Fayeldi, 2017), Mathematic (Ismatullah, 2017; Nawi, etc., 2019), biology (Nurmiati \& Hasan, 2019), and integrated social science (Rumiati, 2020).

Additionally, several studies have shown that the recitation method can increase interest in learning (Purnasari, 2020), active learning (Baitu \& Pane, 2020), student learning outcomes (Tonaiyo, et al., 2020; Solikha, 2020), learning achievement (Erawan, 2020), learning responsibility (Agustini, 2020), active student involvement (Halawa, et al., 2021), building learning motivation (Manalu, 2020), training literacy skills (Afandi, 2020), improving writing skills (Winahyuningsih, 2020), and understand the concept of students (Hermawati, 2020).

So far, nabwu learning in Indonesia uses several media such as nabwu interactive quizzes (Mualimah, et al., 2019) and smartphones (Sulistiyanto \& Wafi, 2018). As for methods such as the manhaji method (Solikha, 2020), eclectic (Askhiya, 2019), Arabic translation pegon (Sa'adah, 2019), sorogan (Jabir \& Wahyu, 2020), Student Teams Achievement Division (STAD) (Utami, 2020), and qiyasi (Mardliyyah, 2019). The online nahwu learning media were used during the pandemic, such as the Arruz application (Sulhadi, 2020) and the spinning wheel (Huda, 2020). While some of the methods used are jigsaw (Anwar \& Sya'bani, 2020), lectures and memorization (Jundi, 2020).

Thus, learning virtual nahwu using the recitation method is feasible for investigations because it has 2 contributions, namely: (1) it can be the point of agreement for Arabic language teachers to build their creativity in teaching, so that they pay attention to what can support the learning process of students and their enthusiasm, especially during the pandemic, (2) the results of the research can be a reference for future research. 


\section{METHOD}

This study used a quasi-experimental method with a pretest-postest control group design pattern. This study's population were all students of the Arabic Language Education study program at STAI Attanwir Bojonegoro from 4 classes totaling 118 students. While the research sample was obtained utilizing random sampling by selecting 1 of the four classes with 34 students and divided into class A, 17 students as the experimental class, and class B, consisting of 17 students as the control class.

Table 1. Research Design

\begin{tabular}{cccc}
\hline Group & Pre-test & Treatment & Post-test \\
\hline Experiment & $\mathrm{E} 1$ & $\mathrm{X} 1$ & $\mathrm{E} 2$ \\
\hline Control & $\mathrm{K} 1$ & $\mathrm{X} 2$ & $\mathrm{~K} 2$ \\
\hline
\end{tabular}

This study uses a variable type of interval resulting from two variables: the independent and dependent variables. In this case, the independent variable is denoted by (XI), namely using the recitation method in learning, and (X2) the effectiveness of using the recitation method in education. Simultaneously, the dependent variable results of virtual nabwu learning from the students of STAI Attanwir Bojonegoro using the recitation method in their learning.

Data collection in this study is in the form of documentation in learning books, student attendance, and syllabus. Observation methods in student activeness and test methods in student ability tests with pre-test and post-test models include material in virtual nabwu learning at STAI Attanwir Bojonegoro. The test instrument used has been tested for validity and reliability before being analyzed in the normality and homogeneity test. And then, the hypothesis testing tool uses $\mathrm{t}$ (t-test).

\section{RESULT AND DISCUSSION}

\section{A Recitation Method for Virtual Nahwu Learning}

The recitation method (giving assignments) is a method of presenting lecture materials where the lecturer assigns specific tasks so that students carry out learning activities. Djamarah \& Zain (2006) argue that assignments carried out by students can be done in the classroom, campus grounds, laboratories, library, student residences, or anywhere as long as the assignment can be done. So the assignments given to students are not limited (the assignments can be done when and where the student is located). Mansyur emphasized that the recitation method is a learning method applied by the teacher, where the teacher gives certain tasks so that students carry out learning activities, then they have to take responsibility for it. Meanwhile, Soekartawi defines that the recitation method is a way of presenting that lessons by giving assignments to students to learn, then be accounted for in front of the class. Besides that the recitation method is often called the assignment method, namely a method where students are given special assignments outside of class hours (Zaenal Aqib and Ali Murtadlo: 2014). 
Sudjana, et al (2007) stated that the recitation method or assignment is a presentation of learning materials where the teacher assigns certain tasks so that students carry out learning activities and provide reports as a result of the assignments they do. The teacher can give assignments in various forms, both independent assignments and group assignments as well as homework assignments that students can do at home, at school and anywhere. The teacher in giving assignments must pay attention to each assignment given to students so that these assignments can improve students' abilities according to the material presented. With the assignment, students will be accountable for what they have done so that the assignment can make it easier for students to understand the subject matter. This method can be used to practice all four language skills, especially in German, which include listening, speaking, reading and writing skills. J.S. Badudu (2003) in the Dictionary of Foreign Absorption Words in Indonesian suggests that the definition of recitation is reading that is conveyed (from rote) in public; memorization that is pronounced (e.g. by students) in front of the class.

Nabwu science in general is tasked with analyzing the position of the $i^{\prime} r a b$ of a sentence in numbers. According to Abu Bakr Muhammad, nahwu is the language of Arabic grammar (Arabic Grammar). As for the term, it is a rule in which it explains the Arabic form, both on its own and in the form of sentence structures. Abdul Hamid (2010) states that nabwu in terminology is a science that studies several rules that can be used to find out various laws of the final conditions of an Arabic word arranged in a sentence, both in terms of $i^{\prime} r a b$ and bina'. Syekh Mustafa al-Ghulayaini defines the science of nabwu is the study of a basis, with which the Arabic sentence forms will be known, both in terms of changes in the final vowel of a sentence and its development (Ghalayainiy, 2008). Nahwu is the rules of language that were born after the existence of language. These rules were taken with the background of errors in language users. Therefore, actually nabwu is studied so that language users can convey language expressions and be able to understand them correctly, both in written form (reading and writing) and in the form of speech (speaking correctly) (Wa Muna, 2011). Historically, the science of nabwu was first compiled by Abu al-Aswad ad-Dualy. Abu Aswad compiled the knowledge of nabwu so that the Arabic language would not be damaged by mixing Arabs with non-Arabs.

During the pandemic, the learning of nahwu science in several schools was carried out virtually. Virtual learning is often referred to as online learning. Salma, et al (2013) revealed that preparation before providing learning services is one of the determining factors in learning success, especially in online learning where there is a distance between teachers and students. In this lesson, the teacher must know the principles of learning and how students learn. Rovai (2002) explains that the delivery tool is not a determining factor for the quality of learning, but the subject design determines learning effectiveness. One of the reasons for choosing a learning method is to promote meaningful learning. The effectiveness of learning can be identified through the behaviors between the teacher and students and how they respond to what is conveyed by the teacher (Ameli, et al., 2020). 
Based on the above opinions, the researchers can conclude that recitation is one of the types of methods offered by the experts mentioned above, which can be applied in the teaching and learning process, where the method is able to actively involve students to support the smooth learning process such as nabwu learning during the pandemic.

\section{The Implementation of Recitation Method for Virtual Nahwu Learning}

Sudjana (2009) emphasizes that the steps of the recitation method are divided into three phases, namely 1) an assignment phase that considers the goals to be achieved, the types of tasks that are clear and precise so that the child understands what is assigned, according to the student's ability, there are instructions, or sources help students work, provide sufficient time to do the task, 2) the task implementation phase with the teacher providing supervision and guidance, the teacher encourages so that students want to work, it is managed/done by the students themselves not telling others, it is recommended that students record the results- the results he got were good and systematic, 3) the phase of being responsible for the assignment in the form of student reports both orally/in writing of what he had done, there were questions and answers/discussions in class, assessment of student work results either by test or non-test or other means.

Likewise, Tambak (2014) explains that the recitation method procedure is divided into three phases, namely 1) the assignment phase consists of setting goals, explaining tasks, and providing timely, 2) carrying out tasks consisting of providing guidance, providing encouragement, providing supervision, and asking learners to record the results of assignments, 3) responsibility for the task consists of asking for reports, holding questions and answers, providing conclusions and giving judgments. Wiryawan (1990) argues that the recitation method procedures that need to be considered in carrying out teaching are six steps, namely 1) deepening students' understanding of the lessons that have been received, 2) training students towards independent learning, 3) being able to divide time regularly, 4) ) take advantage of free time, 5) train themselves to find appropriate ways to complete assignments and 6) enrich the experience at school neglecting activities outside the classroom.

It can be concluded that the procedure for using the recitation method includes several things, namely giving assignments and explanations that must be clearly formulated in advance regarding the tasks that will be carried out by students and the implementation of tasks given to students must be controlled, guided and rewarded every result of assignments done by students.

The recitation method in virtual nabwu learning is the presentation of nabwn learning materials by giving certain tasks according to learning indicators by nahwu lecturers to students, carried out in and outside online classes and the results can be accounted for by students to achieve learning goals. This recitation method is not carried out because most of the learning material is in class, requiring implementation outside of class hours. However, this method must be implemented according to the Nahwu learning indicators set in the Nahwu Lecturer syllabus. If this recitation method is implemented because most of the learning material is in class, this shows the weakness of the lecturer in delivering the material to be delivered. 
In implementing the virtual nahwu learning process at STAI At-Tanwir, lecturers always apply three stages; namely pre-meeting, core activities, and postmeeting because these three things are in accordance with the lesson plan or lesson plan that has been previously prepared by the lecturer before the teaching and learning process takes place (i.e., planning, implementation and assessment). At the planning stage, the lecturer explains the contents of the lesson plans to students. They were divided into several groups for presentations with various materials. For the implementation stage, students play a more active role in carrying out learning activities. They began to be independent in answering questions in the application of the recitation method which was packaged in a group discussion model, refuting answers, also respecting the opinions of friends. This is so that their social skills also begin to be honed little by little. The role of the lecturer here is only to guide and help them if there are difficulties in the process of learning activities. For example, before learning about chapters (e.g., at the third meeting about chapter $i^{\prime} r o b$ ) took place, each group was given the task to find any and any reference about $i^{\prime} r o b$ and learn and understand it. And in the 3rd meeting, the group (in charge) discussed the chapter $i^{\prime} r o b$, based on what they knew from the references they got. Then, at the end of the session the lecturer will provide additions, suggestions, and input regarding the material that has been presented. Whereas at the stage of the assessment of the virtual nahwu learning process with the recitation method, using evaluation of cognitive, affective and psychomotor aspects. The cognitive abilities that have been achieved by students can be seen from the results of their tests, both written tests, daily tests, midterm tests, and final semester tests. In affective ability, the lecturer assesses it from the mutual respect for the opinions of friends, democratic attitudes and the most important and the main purpose of holding the recitation method is their understanding and learning memory. And on psychomotor abilities, lecturers assess the way students implement each material in their daily activities.

In the learning process, there must be advantages and disadvantages. Following are some of the advantages of the recitation method in virtual nahwu learning; 1) more stimulating students in doing individual or group learning activities, 2) can develop their independence outside the supervision of lecturers, 3) can foster student responsibility and discipline, 4) can develop their creativity. The assignment method can make students active in learning. The task stimulates them to learn more, both in class and outside the classroom or with others, whether they are close to the lecturer or far away; This method can develop the independence they need in life; Assignments are more convincing about what will be learned from the lecturer, deepen, enrich, or broaden the view of what is being learned; Tasks can nurture their habit of finding and managing information and communication on their own; This method can make them excited in learning because learning activities can be done with various variations so that they are not boring; This method fosters their responsibility and discipline; This method can develop their creativity. Thus, the researcher concludes that the recitation method has advantages in virtual nabwu learning, namely students learn to get used to taking their initiative, being independent in all the tasks given by the lecturer so that they can strengthen a sense of responsibility because the results done will be accounted for in front of the lecturer. 
While the weaknesses of the recitation method in virtual nabwu learning are; 1) students are difficult to control, are they really doing the assignment or someone else, 2) specifically for group assignments, it is not uncommon for those who actively work on and complete it are only certain members, while other members do not participate well, 3) it is not easy to give assignments that are according to the individual differences of students, 4) often giving monotonous tasks (not varying) can lead to their boredom. Thus, it appears that the implementation of this method demands a lot of the essence of students, because they are always required by the lecturers to study on their own, whether for material that has been explained or that has not been explained. Sometimes the task is done by other people without supervision, students who are too stupid have a hard time learning, maybe the assignment is given but done by someone else, sometimes they copy or imitate their friends' work so that their own experience is not there, sometimes the discussion is less than perfect.

\section{The Effectiveness of Using Recitation Method for Virtual Nahwu Learning}

The effectiveness of using a recitation method in virtual nabwu learning is based on the ability test. This test instrument was first tested using the validity and reliability of each assessment point indicator. The validity test was conducted with 30 respondents with 25 assessment point indicators. Based on the results of the validity test, it is known that the 25 assessment point indicators are valid and reliable. Based on this description, the instrument is suitable for use in research. Before that, the researchers conducted a pre-test data similarity test in the experimental and control groups. The value of an experimental class is 67.94 , and the value of a control class is 66.93, which are summarized in the following diagram:

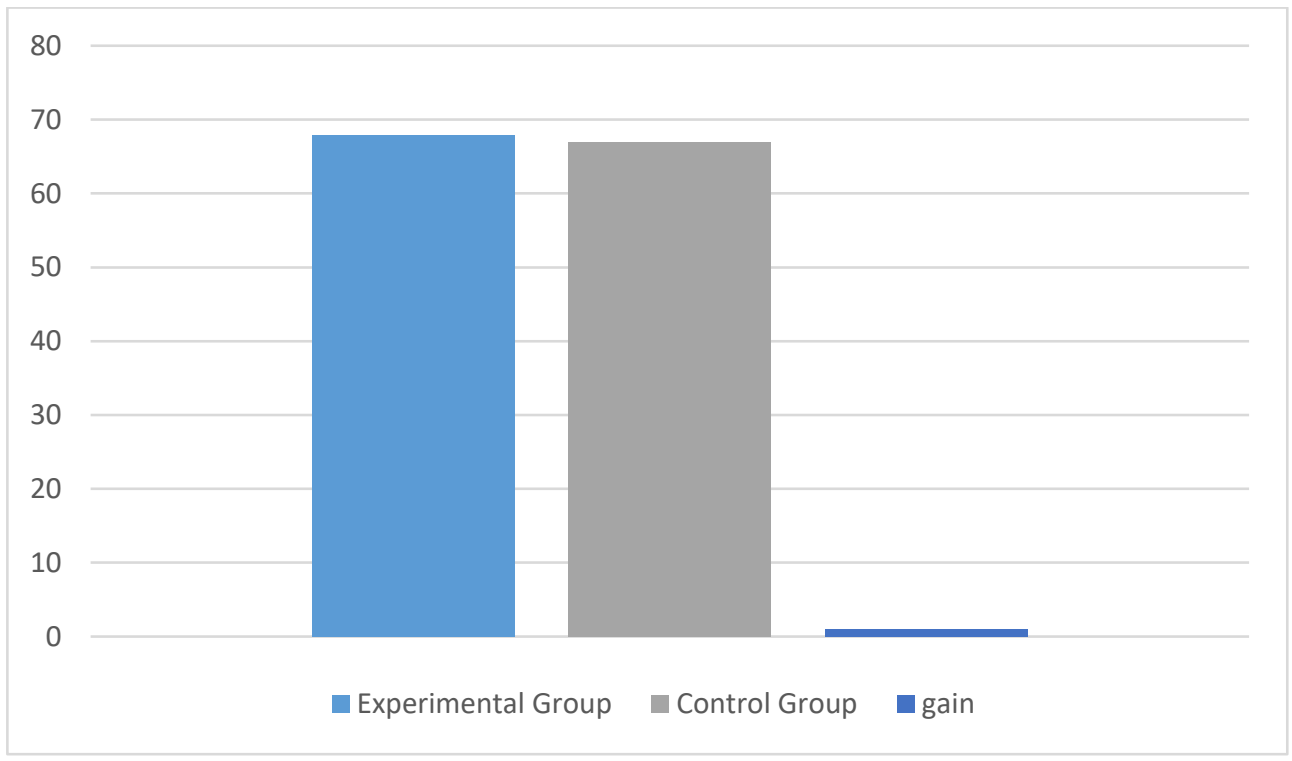

Figure 1. The results of a pre-test group in the experimental and control groups

Then after doing the next test, the post-test value is obtained with the following diagram: 
Ta'lim al-'Arabiyyah : Jurnal Pendidikan Bahasa Arab dan Kebahasaaraban, 5 (1), 2021

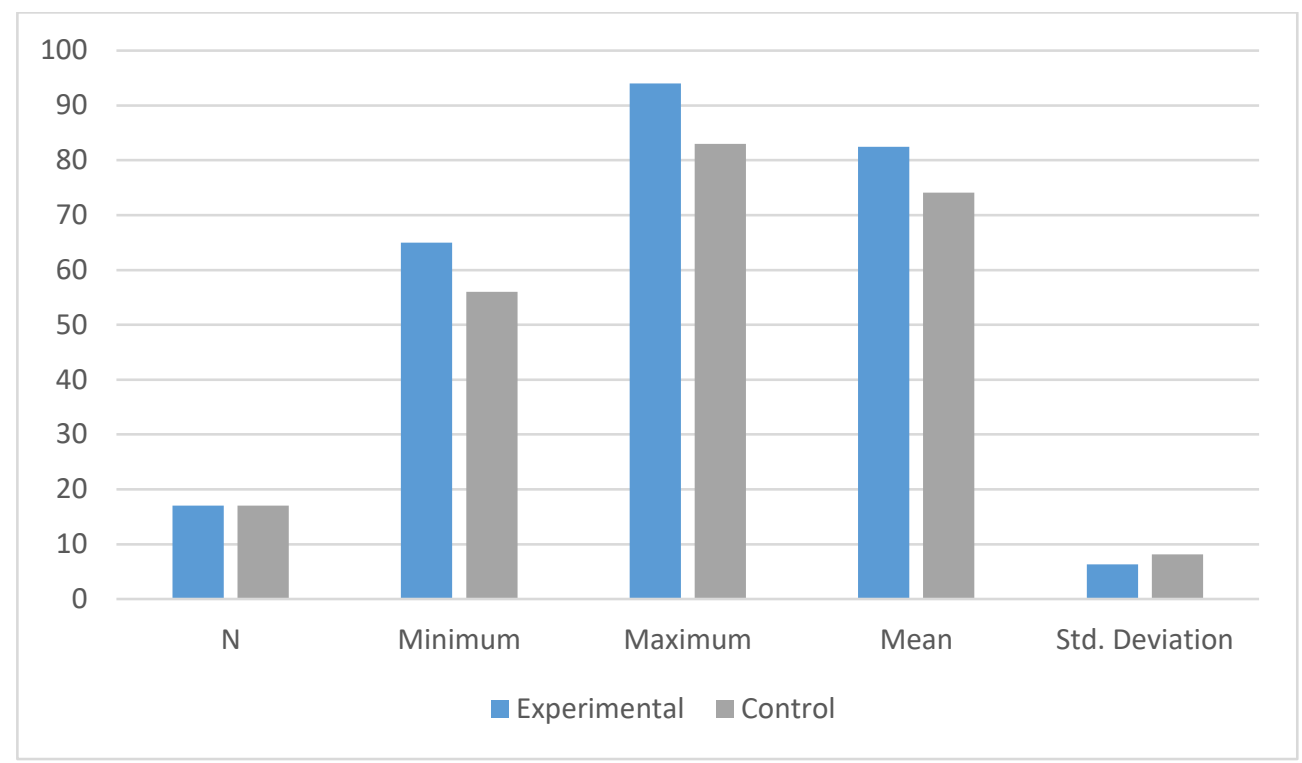

Figure 2. Post-test results data

In the diagram above, these two groups' assessment results have a significant increase in learning outcomes. In this second test, the experimental group was given treatment in material delivery using the recitation method. And in the control group, learning was carried out as usual. The value analysis results found that the experimental group's minimum value was 65 and the control group was 56 . Then, the control group's maximum value reached 94 and the control group 83, which has been summarized in the diagram above. Then based on the results of the first diagram analysis shows the results summarized in the diagram below.

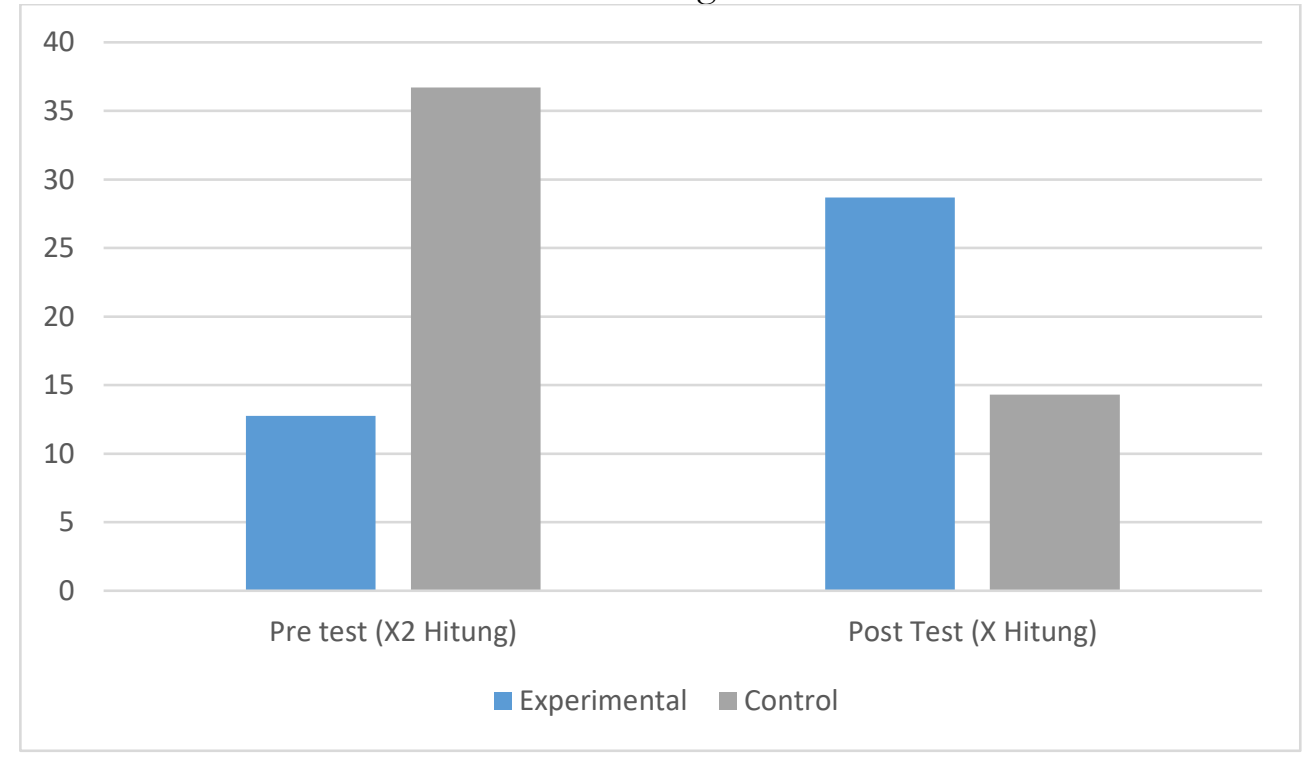

Figure 3. Data Normality Test Results 
Ta'Cim al-'Arabiyyah : Jurnal Pendidikan Bahasa Arab dan Kebahasaaraban, 4 (x), 2020

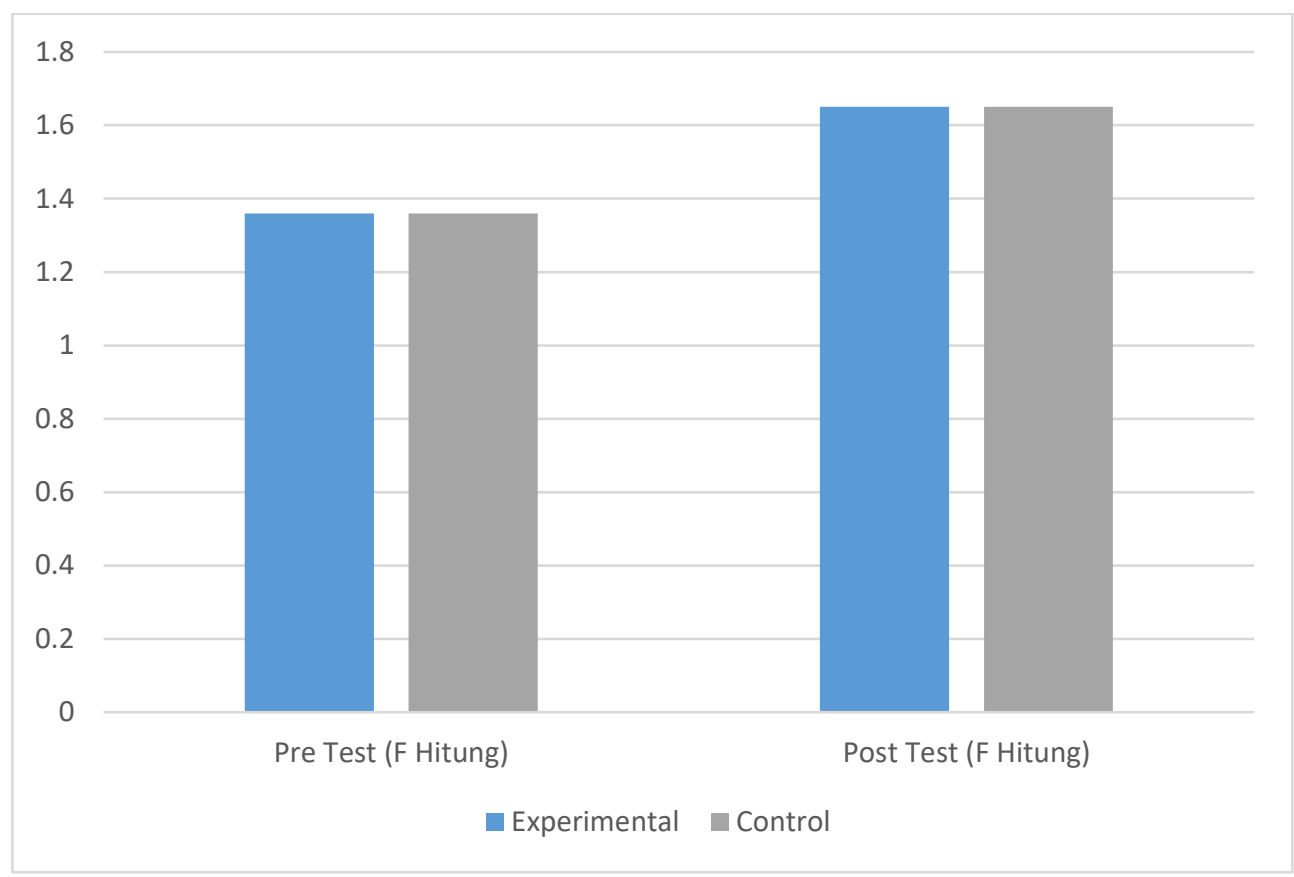

Figure 4. Homogeneity Test Results

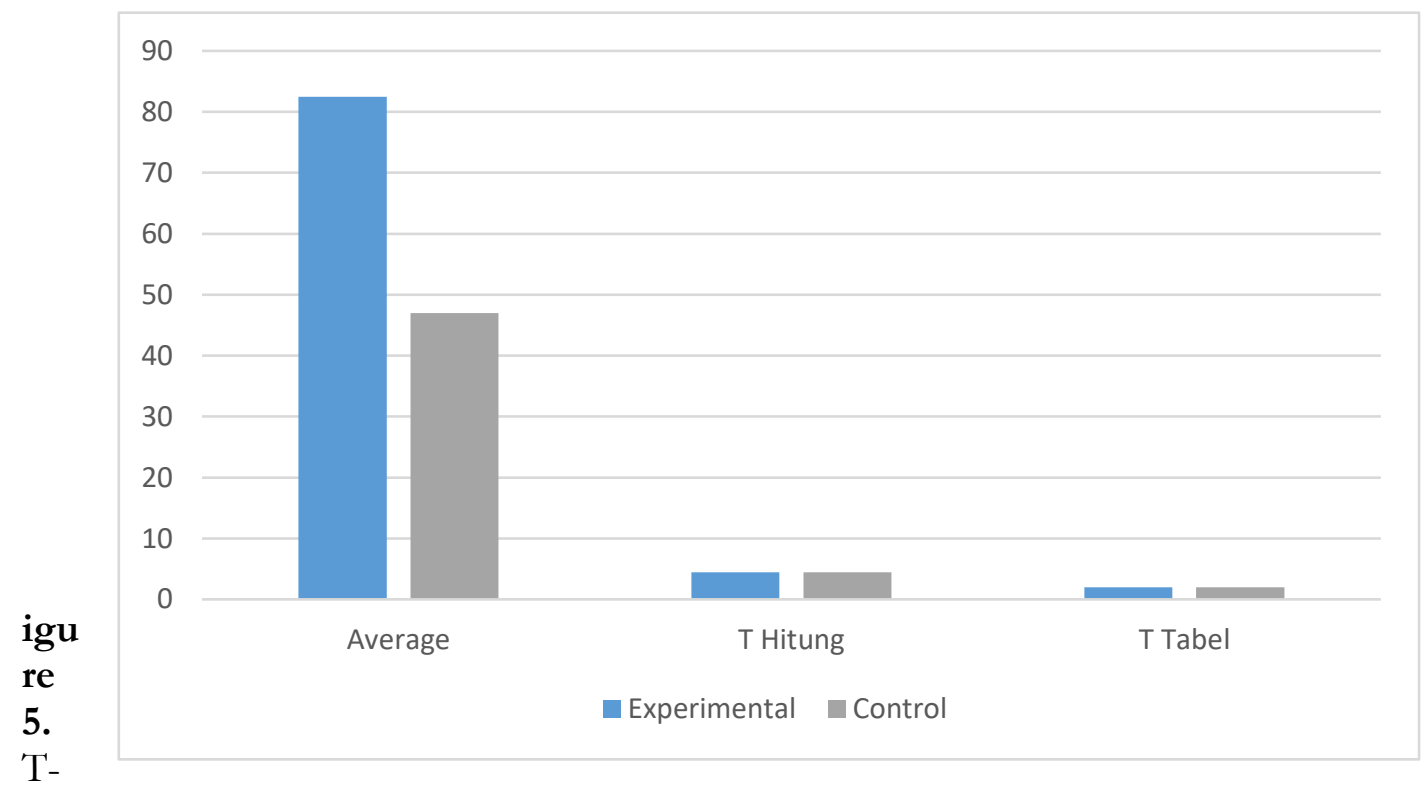

Test Results of Learning Outcomes

The table above explains that the pre-test (X2 Count) shows the value of 12,755 (Experiment) and 36,692 (Control). Whereas the post-test value shows the numbers 28,692 (Experiment) and 14,305 (Control) giving the sense that the normality test results are declared normal because $\mathrm{c}^{2}$ hitung $<\mathrm{c}^{2}$ tabel is 41.34 for $\alpha=5 \%$ and $\mathrm{dk}=28$. 
Whereas in the homogeneity test, the data used two-variant question test or $\mathrm{f}$ test on diagram 3, namely the value of 1.36 in the pre-test $\left(\mathrm{F}_{\text {hitung }}\right)$ of the experiment and control. And the value of 1.65 in the post-test $\left(\mathrm{F}_{\text {hitung }}\right)$ and control experiment, based on this value, it can be concluded that the data is homogeneous because the value of $\mathrm{F}_{\text {hitung }}<\mathrm{F}_{\text {tabel }}$ is 2.13 for $\alpha=5 \%$ with $\mathrm{dk}=(28: 28)$

Then for t-test results on diagram 5 shows an average value of 82.46 (Experiment) and 74.01 (Control) and the value of $t_{\text {hitung }}=4.409>t_{\text {tabel }}=2.00$ at $\alpha=$ $5 \%$ with $\mathrm{dk}=56$ is obtained. The research hypothesis $(\mathrm{Ha})$ states an increase in virtual nabwu learning using the recitation method, which is accepted.

\section{CONCLUSION}

Overall, the application of the recitation method in virtual nabwu learning went well and smoothly. In its application there are three stages, namely: assignment of tasks, implementation of tasks, and assessment or evaluation. Giving assignments are given so that students play an active role in learning, which must be followed by implementation (discussing material with each group member, explaining briefly and clearly about previous topics or learning materials, answering questions raised by other groups, debunking the answers if any answers from presenters that are not understood by other groups). The last stage is assessment (evaluation through three aspects, namely cognitive, affective and psychomotor aspects). After applying the recitation method, their learning creativity got better. This can be seen from their activeness in explaining the learning material and in answering questions raised by other groups.

Even though the implementation of virtual nabwu learning with the recitation method went well, in reality the implementation still faced obstacles. These constraints are technical and non-technical in nature. From the technical constraints, namely the application of the recitation method is very time consuming, especially to get a better understanding and learning memory of students, this method must be combined with methods that can explore student activeness such as the discussion method. As in the 2013 curriculum, it is mandatory for students to be active in the learning process. From the non-technical constraints, namely from the teachers and students themselves, such as their different attitudes and abilities. Thus, the process of planning, implementing, and evaluating virtual nabwu learning using the recitation method needs to be addressed and improved from various aspects.

\section{REFERENCES}

Afandi, M. F. (2020). Pengembangan modul al jabar berbasis metode resitasi untuk melatih kemampuan literasi Matematika. (Doctoral dissertation, UIN Sunan Ampel Surabaya).

Agustini, M. (2020). Penerapan Metode Resitasi Terbadap Peningkatan Tanggung Jawab Belajar Siswa Pada Mata Pelajaran Pendidikan Agama Islam Kelas Iv di Sekolah Dasar Negeri 187 Kota Palembang (Doctoral dissertation, Universitas Muhammadiyah Palembang).

Ahmadi, Ilmiani, A. M. (2020). The Use of Teaching Media in Arabic Language Teaching During Covid-19 Pandemic. Dinamika Ilmu, 20(2), 307-322. 
Akmaliyah, A., Karman, K., Rosyid Ridho, M., \& Khomisah, K. (2020). Online-based teaching of Arabic translation in the era of Covid 19 pandemic restrictions. IOSR Journal of Humanities and Social Science (IOSR-JHSS), 25(5), 13-22.

Ameli, A., Hasanah, U., Rahman, H., \& Putra, A. M. (2020). Analisis keefektifan pembelajaran online di masa pandemi COVID-19. Mahaguru: Jurnal Pendidikan Guru Sekolah Dasar, 2(1), 28-37.

Anwar, K., \& Sya'bani, M. Z. (2020). Penerapan Pembelajaran Kooperatif Tipe Jigsaw Berbasis Online Lerning untuk Meningkatkan Hasil Belajar Nahwu. An Naba, 3(2), 122-133.

Aqib, Zainal \& Ali Murtadlo. Kumpulan Metode Pembelajaran. Bandung: Sarana.

Askhiya, U. (2019). Pembelajaran Nabwu Dengan Metode Eklektik Di Kelas X Jurusan Keagamaan Madrasab Aliyah Miftabul Huda Rawalo Banyumas. (Doctoral dissertation, IAIN).

Badudu, J.S. (2003). Kamus Kata-kata Serapan Asing Dalam Bahasa Indonesia. Jakarta : Kompas.

Baitu, M., \& Pane, L. A. (2020). Penggunaan Metode Pembelajaran Resitasi/Penugasan dalam Meningkatkan Keaktifan Belajar Siswa pada Mata Pelajaran IPS Siswa Kelas VII SMP Negeri 1 Batu Atas. Jurnal Pendidikan Sejarah, 48-62.

Blignault I, Saab H, Woodland L, Comino E. Evaluation of the acceptability and clinical utility of an Arabic-language mindfulness CD in an Australian community setting. Transcultural Psychiatry. 3(56) (2019):552-568.

Djamarah \& Zain. (2006). Strategi belajar mengajar. Jakarta: Rineka Cipta.

Erawan Aidid, M. P. (2020). Meningkatkan Prestasi Belajar Melalui Metode Resitasi. CV. Bayfa Cendekia Indonesia.

Halawa, E., \& Chrismastianto, I. A. W. (2021). Penerapan Metode Resitasi Untuk Meningkatkan Keterlibatan Aktif Siswa Dalam Pencapaian Tujuan Pembelajaran Sejarah Kelas X-IPS. Kumpulan Artikel Ilmiah Rumpun Ekonomi dan Ilmu Sosial, 1(1), 54-78.

Halik, A., \& Yusfira, Y. (2019). Penerapan Metode Resitasi dalam Meningkatkan Prestasi Belajar Peserta Didik Pada Mata Pelajaran Pendidikan Agama Islam Di SMA Negeri 1 Wajo. Istiqra', 7(1).

Hermawati, M. (2020). Peningkatan pemahaman konsep siswa melalui program resitasi berbasis contrasting case pada materi listrik statis. (Doctoral dissertation, Universitas Negeri Malang).

Hilmi, D., \& Ifawati, N. I. (2020). Using The Blended Learning As An Alternative Model Of Arabic Language Learning In The Pandemic Era. Arabi: Journal of Arabic Studies, 5(2), 117-129. 
Ta'lim al-'Arabiyyah : Jurnal Pendidikan Bahasa Arab dan Kebahasaaraban, 5 (1), 2021

Huda, N. F. (2020). Penggunaan Media Pembelajaran Spinning Wheel dalam Pembelajaran Qawaid Nahwu. Lisanan Arabiya: Jumal Pendidikan Bahasa Arab, $4(2), 155-174$.

Ibrahim, N. R. A. Z. (2020). E-Learning Problems In Arabic Language And Islamic Courses During The Corona Pandemic. PalArch's Journal of Archaeology of Egypt/Egyptology, 17(6), 9074-9080.

Isani MA. (2021). Methodological Problems of Using Arabic-Language Twitter as a Gauge for Arab Attitudes Toward Politics and Society. Contemporary Review of the Middle East. 1(8), 22-35.

Ismatullah, K. (2017). Penerapan Metode Pembelajaran Resitasi Dalam Pembelajaran Matematika Dasar. Edumatic: Jurnal Pendidikan Informatika, 1(1), 24-28.

Jabir, M., \& Wahyu, W. (2020). Efektivitas Metode Sorogan Terhadap Pembelajaran Nahwu di Pondok Pesantren Raudhatul Mustofah Lilkhairat. Albariq: Jurnal Pendidikan Bahasa Arab, 1(1), 13-24.

Jasni, N. S. B., \& Ardiansyah, A. A. (2020). Arabic Learning Based On E-Learning Using Arabic Teacher Website In The Pandemic Era Of Covid-19. Ta'lim al'Arabiyyah: Jurnal Pendidikan Bahasa Arab \& Kebahasaaraban, 4(2), 122-137.

Jazeeh, A. S., Mahmood, M. A., Jasim, K. J., \& Shamkali, N. B. (2021). Arabic Language Department Students' Cognitive Structure Under Corona Virus (COVID-19) Pandemic. Psychology and Education Journal, 58(3), 1529-1539.

Jundi, M. (2020). Persepsi Mahasiswa terhadap Pelaksanaan Perkuliahan Nahwu dengan Sistem Daring. Al-Ma rifah: Jurnal Budaya, Babasa, dan Sastra Arab, 17(2), 105-118.

Mabruri, M., \& Hamzah, H. (2021). The Urgency of Using Internet-Based Arabic Learning Media in Online Learning in the Global Pandemic Era. Loghat Arabi: Jurnal Bahasa Arab dan Pendidikan Bahasa Arab, 1(2), 1-10.

Manalu, F. (2020). Penerapan metode resitasi untuk membangun motivasi belajar siswa pada pembelajaran daring. (Doctoral dissertation, Universitas Pelita Harapan).

Mardliyyah, A. (2019). Implementasi Metode Qiyasi dalam Pembelajaran Nahwu Kelas XI Ma Ibnu Qoyyim Putra Yogyakarta. At-Tarbawi: Jurnal Kajian Kependidikan Islam, 4(2), 158.

Mariyam, S., Triwoelandari, R., \& Nawawi, H. K. (2018). Pengaruh Metode Resitasi Terhadap Motivasi Belajar Pendidikan Agama Islam (PAI) Siswa Kelas VII SMP Pembangunan Bogor. E-Jurnal Mitra Pendidikan, 2(11), 1282-1296.

Moghazy, M. A. (2020). Teaching and learning Arabic as a second language online: A case study of Dubai during COVID-19 pandemic. (Doctoral dissertation, University of Illinois at Urbana-Champaign).

Mualimah, A., Praherdhiono, H., \& Adi, E. P. (2019). Pengembangan Kuis Interaktif Nahwu Sebagai Media Pembelajaran Drill and Practice Pada Pembelajaran 
Ta'lim al-'Arabiyyah : Jurnal Pendidikan Bahasa Arab dan Kebahasaaraban, 4 (x), 2020

Nahwu Di Pondok Pesantren Salafiyah Putri Al-Ishlahiyah Malang. Jurnal Kajian Teknologi Pendidikan, 2(3), 203-212.

Murniasih, T. R., \& Fayeldi, T. (2017). Metode Resitasi untuk Meningkatkan Pemahaman Konsep pada Mata Kuliah Dasar-Dasar Pemrograman Komputer. Jurnal Edukasi, 4(1), 8-12.

Nawi, A. R., Rahmawati, N. K., \& Iswadi, I. (2019). Penerapan Hasil Belajar Matematika Menggunakan Metode Drill Dan Resitasi Pada Materi Bangun Datar Segitiga. Buana Matematika: Jurnal Ilmiah Matematika dan Pendidikan Matematika, 9(1), 13-18.

Nurcholis, A., Harianto, B., \& Machmudah, U. (2021, April). Implementation of Hard and Soft Technology in Learning Arabic During the Covid-19 Pandemic. In International Conference on Engineering, Technology and Social Science (ICONETOS 2020) (pp. 8-15). Atlantis Press.

Pereira N, Bakhiet SF, Gentry M, Balhmar TA, Hakami SM. (2017). Sudanese Students' Perceptions of Their Class Activities: Psychometric Properties and Measurement Invariance of My Class Activities-Arabic Language Version. Journal of Advanced Academics. 2(28), 141-159.

Prawiradilaga, Dewi Salma, etc. (2013). Mozaik Teknologi Pendidikan E-Learning. Jakarta: Prenada Media.

Purnasari, N. (2020). Kajian Metode Discovery Learning Dan Resitasi Dalam Meningkatkan Minat Belajar Ipa Siswa Sd. At-Tarbawi: Jumal Kajian Kependidikan Islam, 5(2).

Rovai, A. P. (2002). Building Sense of Community at a Distance. The International Review of Research in Open and Distributed Learning, 3(1).

Rumiati, E. (2020). Penggunaan Metode Resitasi untuk Meningkatkan Hasil Belajar Siswa pada Pembelajaran IPS Terpadu tentang Letak Geografis dan Koordinat Negara Asean (Penelitian Tindakan Kelas di Kelas VIII-G SMPN 6 Tasikmalaya). Jurnal Wabana Pendidikan, 7(2), 211-222.

Sa'adah, N. (2019). Problematika Pembelajaran Nahwu Bagi Tingkat Pemula Menggunakan Arab Pegon. Lisanan Arabiya: Jurnal Pendidikan Bahasa Arab, 3(1), 15-32.

Sholikha, M. A. (2020). Implementasi Metode Manhaji dalam Pembelajaran Nahwu Shorof di Manhaji Course. Academica: Journal of Multidisciplinary Studies, 2(1), 179-188.

Solikha, M. (2020). Meningkatkan Hasil Belajar Peserta Didik MI Rahmatul Umat 01 Walangsanga Moga Pemalang Metode Resitasi. Indonesian Journal of Educationalist, 1(2), 211-218.

Speaker RB Thomure HT, "Arabic Language Arts Standards: Revolution or Disruption?," Research in Comparative and International Education 13, no. 4 (2018): 551-69. 
Ta'lim al-'Arabiyyah : Jurnal Pendidikan Bahasa Arab dan Kebahasaaraban, 5 (1), 2021

Sudjana, Nana. (2009). Dasar-Dasar Proses Belajar Mengajar. Bandung: Sinar Baru Algesindo.

Sulhadi, A. (2020). Media Pembelajaran Bahasa Arab Berbasis Android Dengan Menggunakan Aplikasi Arruz Untuk Penguasaan Nahwu Di Jurusan Sastra Arab UIN Sunan Kalijaga Yogyakarta. El-Tsaqafab: Jurnal Jurusan PBA, 19(1), 37-55.

Sulistiyanto, S., \& Wafi, A. (2018). Media Pembelajaran Nahwu Dengan Smartphone. Seminastika, 1(1), 171-175.

Supriatna, Nana. etc. (2007). Pendidikan IPS di SD. Bandung: UPI Press.

Tambak, Syahraini. (2014). Metode Ilmiah dan Inovatif Pendidikan Agama Islam. Yogyakarta: Graha Ilmu.

Tayyara A El-Rahman. (2020). The Practicability of Proverbs in Teaching Arabic Language and Culture, Language Teaching Research.

Thohir, M., \& Muslimah, K. C. (2020). Evaluation of Arabic Learning Outcomes using Google Form during School Quarantine due to Covid-19 Pandemic. Evaluation, 4(1), 12-22.

Tonaiyo, H., Ilato, R., \& Isa, R. (2020). Penerapan Metode Resitasi Dalam Meningkatkan Hasil Belajar Siswa. Jambura Economic Education Joumal, 2(1), 1218.

Utami, R. (2020). Ta'līm Al-Nahw Bi Madkhal Al-Ta'allum Al-Ta'āwunī Bi Uslūb (STAD) Bi Ma’had Dār Al-'Ulūm Al-'Ashrī Banda Aceh. Ta'lim al-'Arabiyyab: Jurnal Pendidikan Bahasa Arab \& Kebabasaaraban, 4(2).

Wargadinata, W., Maimunah, I., Febriani, S. R., \& Humaira, L. (2020). Mediated Arabic Language Learning for Higher Education in COVID-19 Situation. Izdihar: Journal of Arabic Language Teaching, Linguistics, and Literature, 3(1), 59-78.

Winahyuningsih, C. E. (2020). Memperbaiki Kemampuan Menulis Cerpen Siswa Smk Dengan Metode Resitasi Berbasis Pengalaman Pribadi. Jurnal Ilmiah Pendidikan Trisala, 3(18), 13-13.

Yahya, M., Maftuhati, M., Mustofa, A. H., \& Arifa, Z. (2021). Online-Based Arabic Learning Management During the Covid-19 Pandemic Era: Plan, Implementation and Evaluation. Al-Ta'rib: Jurnal Ilmiah Program Studi Pendidikan Babasa Arab IAIN Palangka Raya, 9(1). 